\title{
Bariatric Surgery and Fertility
}

\section{Burhan MAYIR ${ }^{1}$ id, Yeliz AKPINAR MAYIR ${ }^{2}$ iD}

${ }^{1}$ Clinic of General Surgery, Antalya Training and Research Hospital School of Medicine, Antalya, Turkey

${ }^{2}$ Clinic of Gynecology and Obstetrics, Antalya Training and Research Hospital School of Medicine, Antalya, Turkey

\section{ABSTRACT}

Reproductive concerns and pregnancy outcomes after bariatric surgery is performed are important issues for patients, general surgeons, and obstetrics and gynecology specialists. Although there are no official guidelines available concerning the pregnancy outcome after bariatric surgery is performed, being pregnant after bariatric surgery is performed seems to be safe. However, conception is not recommended within the first year of undergoing bariatric surgery when there is rapid weight loss. Patients must be carefully evaluated before conception, and necessary supplements such as vitamins and folic acid must be recommended.

Keywords: Obesity, bariatric surgery, fertility, pregnancy

\section{Introduction}

Obesity is an important public health problem. The incidence rate of obesity is rising worldwide because of changes in nutritional habits and life conditions. In Turkey, the rate of obesity was $17.2 \%$ in 2012 according to the Turkish Statistical Institute. The rate was $20.9 \%$ among women and $13.7 \%$ among men. When we consider the rate in 2008 , which was $15.2 \%$, we can see a quick rise in the rate of obesity (1). According to World Health Organization data, in 2014, the rates of obesity globally and in Europe were $13 \%$ and $25 \%$, respectively (2).

Type 2 diabetes mellitus, hypertension, heart diseases, ischemic stroke, and hyperlipidemia are concomitant obesity-related diseases (3). Malignancies such as colon, prostate, and breast cancers are also correlated with obesity. Adequate weight loss cannot be achieved in morbidly obese patients in spite of regular diet consumption, exercising, and medical treatment (4). As a result, the surgical approach for treating morbid obesity has improved. Different surgical methods have been used to date. Operations can be grouped as restrictive, malabsorptive, or a combination of both (5). Long-term surveys found the morbidity rate to be lower in patients who lost weight after undergoing bariatric surgery than in obese patients $(6,7)$.

Half of all bariatric surgery procedures are performed in women aged $18-45$ years (8). This rate was $64 \%$ in our case series. This age range includes the reproductive period. Therefore, reproductive concerns and pregnancy outcomes are important issues for patients, general surgeons, and obstetrics and gynecology specialists. There are no official guidelines available for pregnancy after bariatric surgery is performed. Studies are observational and include few patients; therefore, it is difficult to define the exact outcome. In this article, we aimed to gather information about reproductive concerns and pregnancy outcomes after bariatric surgery is performed to date.

\section{Effect of obesity on reproduction}

Although not proven, it is thought that obesity has an unfavorable effect on fertility. Menstrual cycles are more irregular and longer in obese women. In the study by Santoro et al. (9), urinary levels of luteinizing hormone (LH) and follicle stimulating hormone (FSH) were low in obese women. This shows the lower secretion of reproductive hormones and

Cite this article as: Mayir B, Akpınar Mayir Y. Bariatric Surgery and Fertility. Bezmialem Science 2018; 6: 63-6. 
lower function of corpus luteum in obese women. Ovarian reserves in obese women during the late reproductive period were more reduced (10). In two studies assessing hormonal levels after bariatric surgery, serum estradiol levels decreased and FSH levels increased $(11,12)$. In another experimental study, fertility declined in mice that were made obese with diet alterations, and this declined level normalized after diet modifications (13). In obese women, polycystic ovary syndrome (PCOS) is seen more frequently; therefore, ovulation problems and anovulation are more common. Spontaneous pregnancies are seen after bariatric surgeries in women with PCOS who cannot get pregnant before the operation bariatric surgery (14). In a study, a normal menstrual cycle was achieved in 70 of 98 women $(71.4 \%)$ who were anovulatory before undergoing bariatric surgery (15). All this indicates an unfavorable effect of obesity on fertility and increased rates of fertility after bariatric surgery.

\section{Duration period for conception after bariatric surgery}

There are different results from few studies on this subject. In a study by Dao et al. (16), the same outcomes for the mother and the baby were observed in 21 patients who got pregnant within the first year after undergoing gastric bypass operation when compared with 13 patients who got pregnant 1 year after undergoing bariatric surgery. However, in another study, preterm birth rates were reported to be high if the pregnancy occurred within the first year of laparoscopic gastric bypass operation (17). Even if there are not enough evidence-based data about this subject, pregnancy is not recommended, particularly within the first year following bariatric surgery because of rapid weight loss. A common time to get pregnant is approximately 18 to 24 months after undergoing bariatric surgery (18-20).

\section{Contraception methods after bariatric surgery}

Pregnancies in the early period of bariatric surgery are not recommended; therefore, contraception is extremely important. The efficacy of oral contraceptive medicines may be reduced after malabsorptive procedures due to failure in absorption (18). In case of diarrhea and vomiting, the efficacy of oral contraceptives decreased further. Two pregnancies were detected among nine patients using oral contraceptives after making a biliopancreatic diversion (21). Oral intake or intramuscular injection of contraceptive medicines containing progesterone is not suitable for these patients because of their potential to gain weight (22). Intrauterine devices may cause additional menstrual irregularities. Intrauterine devices with progestogen seem to be the most useful contraceptive method for this group of patients (23).

\section{Maternal and fetal outcomes of pregnancies after bariatric surgery}

Obesity carries some risks to the mother and the baby during pregnancy. Nearly half of maternal deaths are caused by thromboembolisms and cardiac diseases that are close related to obesity. In addition, preeclampsia, gestational diabetes, hypertension, abortion, complication due to anesthesia, and wound infections are commonly seen in obese pregnant women (23). The stillbirth rate and neonatal mortality rate are high in obese pregnant women. Some studies have shown a decrease in material and fetal complication rates after bariatric surgery is performed (24-29).

In a study evaluating results after laparoscopic gastric banding (LAGB), gestational diabetes and pregnancy-induced hypertension rate were found to be $8 \%$ and $8 \%$, respectively, in LAGB pregnancies. The corresponding rates were higher in non-LAGB pregnancies at $27 \%$ and $22.5 \%$, respectively (30). In another two studies evaluating pregnancy outcomes after gastric bypass, the rates of complications, such as those of gestational diabetes and preeclampsia, decreased or remained the same (8).

Some complications might be seen during pregnancy after bariatric surgery is performed. Most of them are internal hernias, perforations due to ulcers, ileus due to adhesions, strictures at the stapler tract, and complications due to the gastric band. Because these complications might occur in non-pregnant patients, we cannot be sure if they are related to pregnancy. However, maternal and fetal mortality and morbidity rates associated with these types of complications are high (31).

For preventing complications due to the gastric band, deflating or extracting the gastric band might be necessary during pregnancy. Deflation of the gastric band up to 6 months after delivery or a total removal of the gastric band has been recommended (32).

\section{Nutritional support in pregnancy after bariatric surgery}

Mostly seen deficiencies after bariatric surgery is performed are iron, vitamin B12, calcium, and folic acid deficiency. After malabsorptive procedures in particular, absorption from the duodenum and the proximal part of the jejunum decreases. The correction of these deficiencies is important (23). Performing complete blood count and measuring the serum levels of ferritin; folic acid; vitamins A, B1, B6, D, and E; calcium, selenium, zinc, magnesium, and albumin are essential for women who are planning on getting pregnant. Supplementing folic acid during the pregestational period is important for the prevention of fetal neural tube defects due to folic acid deficiency (33). During the gestational period, iron, calcium, vitamin $\mathrm{D}$, and folic acid supplementation is essential (34). Generally, oral treatments are adequate, but in few cases, parenteral treatment may be necessary. Parenteral treatment is required, particularly after making a biliopancreatic diversion.

An important dilemma concerning pregnancies after bariatric surgery is performed is whether the oral glucose tolerance test (OGTT) should be performed. Performing the test on patients who have undergone malabsorptive surgeries can 
cause dumping syndrome. For this reason, the test should not be performed. Instead of the OGTT, the fasting blood sugar level and postprandial blood sugar level at the second hour between the $24^{\text {th }}$ and $28^{\text {th }}$ week of pregnancy can be performed $(23,24)$.

\section{Male infertility and bariatric surgery}

There are few studies considering infertility in obese male patients. Testosterone levels decrease in obese males; meanwhile, estrogen levels increase. After performing bariatric surgery, estradiol levels decrease, but total and free testosterone levels increase (35). These prove that there is an increase in male fertility after performing bariatric surgery. However, in one study, secondary infertility has been reported in men after performing gastric bypass surgery. The authors stated that insufficient absorption of nutrients essential for spermatogenesis may be the cause (36).

\section{Conclusion}

Being pregnant after bariatric surgery is performed seems to be safe. However, conception is not recommended within the first year after undergoing bariatric surgery when there is rapid weight loss. Patients must be carefully evaluated before conception, and necessary supplements such as vitamins and folic acid must be recommended. The close follow-up of these patients during pregnancy is important.

Peer-review: Externally peer-reviewed.

Author Contributions: Concept - B.M., Y.A.M.; Design - B.M., Y.A.M.; Supervision - B.M.; Resource - B.M., Y.A.M.; Materials B.M., Y.A.M.; Data Collection and/or Processing - B.M., Y.A.M.; Analysis and/or Interpretation - B.M., Y.A.M.; Literature Search - B.M., Y.A.M.; Writing - B.M., Y.A.M.; Critical Reviews - B.M., Y.A.M.

Conflict of Interest: No conflict of interest was declared by the authors.

Financial Disclosure: The authors declared that this study has received no financial support.

\section{References}

1. Turkish Statistical Institute. Available at http://www.tuik.gov. tr/PreHaberBultenleri.do?id=13490. Accessed 28 March 2017.

2. World Health Organization. Available at http://www.who.int/gho/ ncd/risk_factors/overweight_text/en. Accessed 28 March 2017.

3. Pi-Sunyer FX. A review of long-term studies evaluating the efficacy of weight loss in ameliorating disorders associated with obesity. Clin Ther 1996; 18: 1006-35. [CrossRef]

4. Li Z, Maglione M, Tu W, Mojica W, Arterburn D, Shugarman LR, et al. Meta-analysis: pharmacologic treatment of obesity. Ann Intern Med 2005; 142: 532-46. [CrossRef]

5. Saber AA, Elgamal MH, McLeod MK. Bariatric surgery: the past, present, and future. Obes Surg 2008; 18: 121-8. [CrossRef]

6. Adams TD, Gress RE, Smith SC, Halverson RC, Simper SC, Rosamond WD, et al. Long-term mortality after gastric bypass surgery. N Engl J Med 2007; 357: 753-61. [CrossRef]
7. Sjostrom L, Narbro K, Sjostrom CD, Karason K, Larsson B, Wedel $\mathrm{H}$, et al. Effects of bariatric surgery on mortality in Swedish obese subjects. N Engl J Med 2007; 357: 741-52. [CrossRef]

8. Maggard MA, Yermilov I, Li Z, Maglione M, Newberry S, Suttorp $M$, et al. Pregnancy and fertility following bariatric surgery: a systematic review. JAMA 2008; 300: 2286-96. [CrossRef]

9. Santoro N, Lasley B, McConnell D, Allsworth J, Crawford $S$, Gold EB, et al. Body size and ethnicity are associated with menstrual cycle alterations in women in the early menopausal transition: the Study of Women's Health across the Nation (SWAN) Daily Hormone Study. J Clin Endocrinol Metab 2004; 89: 2622-31. [CrossRef]

10. Merhi ZO. Impact of bariatric surgery on female reproduction. Fertil Steril 2009; 92: 1501-8. [CrossRef]

11. Bastounis EA, Karayiannakis AJ, Syrigos K, Zbar A, Makri GG, Alexiou $\mathrm{D}$. Sex hormone changes in morbidly obese patients after vertical banded gastroplasty. Eur Surg Res 1998; 30: 43-7. [CrossRef]

12. Gerrits EG, Ceulemans R, van Hee R, Hendrickx L, Totte E. Contraceptive treatment after biliopancreatic diversion needs consensus. Obes Surg 2003; 13: 378-82. [CrossRef]

13. Wang JG, Tortoriello DV. Subfertility associated with dietaryinduced obesity in female $\mathrm{Dba} / 2 \mathrm{j}$ mice can be reversed by diet modification. Fertil Steril 2005; 84: S382-3. [CrossRef]

14. Eid GM, Cottam DR, Velcu LM, Mattar SG, Korytkowski MT, Gosman G, et al. Effective treatment of polycystic ovarian syndrome with Roux-en-Y gastric bypass. Surg Obes Relat Dis 2005; 1: 77-80. [CrossRef]

15. Teitelman M, Grotegut CA, Williams NN, Lewis JD. The impact of bariatric surgery on menstrual patterns. Obes Surg 2006; 16: 1457-63. [CrossRef]

16. Dao T, Kuhn J, Ehmer D, Fisher T, McCarty T. Pregnancy outcomes after gastric-bypass surgery. Am J Surg 2006; 192: 762-6. [CrossRef]

17. Patel JA, Patel NA, Thomas RL,Nelms JK, Colella JJ. Pregnancy outcomes after laparoscopic Roux-en-Y gastric bypass. Surg Obes Relat Dis 2008; 4: 39-45. [CrossRef]

18. Paulen ME, Zapata LB, Cansino C, Curtis KM, Jamieson DJ. Contraceptive use among women with a history of bariatric surgery: a systematic review. Contraception 2010; 82: 86-94. [CrossRef]

19. Narayanan RP, Syed AA. Pregnancy Following Bariatric Surgery-Medical Complications and Management. Obes Surg 2016; 26: 2523-9. [CrossRef]

20. Mahawar KK, Graham Y, Small PK. Optimum time for pregnancy after bariatric surgery. Surg Obes Relat Dis 2016; 12: 1126-8. [CrossRef]

21. Gerrits EG, Ceulemans R, van Hee R, Hendrickx L, Totte E. Contraceptive treatment after biliopancreatic diversion needs consensus. Obes Surg 2003; 13: 378-82. [CrossRef]

22. Ostrowska L, Lech M, Stefańska E, Jastrzębska-Mierzyńska M, Smarkusz J. The use of contraception for patients after bariatric surgery. Ginekol Pol 2016; 87: 591-3. [CrossRef]

23. Uzoma A, Keriakos R. Pregnancy management following bariatric surgery. J Obstet Gynaecol 2013; 33: 109-14. [CrossRef]

24. Dalfra MG, Busetto L, Chilelli NC, Lapolla A. Pregnancy and foetal outcome after bariatric surgery: a review of recent studies. J Matern Fetal Neonatal Med 2012; 25: 1537-43. [CrossRef]

25. Karmon A, Sheiner E. Pregnancy after bariatric surgery: a comprehensive review. Arch Gynecol Obstet 2008; 277: 381-8. [CrossRef] 
26. Magdaleno R Jr, Pereira BG, Chaim EA, Turato ER. Pregnancy after bariatric surgery: a current view of maternal, obstetrical and perinatal challenges. Arch Gynecol Obstet 2012; 285: 559-66. [CrossRef]

27. Grundy MA, Woodcock S, Attwood SE. The surgical management of obesity in young women: consideration of the mother's and baby's health before, during, and after pregnancy. Surg Endosc 2008; 22: 2107-16. [CrossRef]

28. Beard JH, Bell RL, Duffy AJ. Reproductive considerations and pregnancy after bariatric surgery: current evidence and recommendations. Obes Surg 2008; 18: 1023-7. [CrossRef]

29. González I, Lecube A, Rubio MÁ, García-Luna PP. Pregnancy after bariatric surgery: improving outcomes for mother and child. Int J Womens Health 2016; 8: 721-9. [CrossRef]

30. Skull AJ, Slater GH, Duncombe JE, Fielding GA. Laparoscopic adjustable banding in pregnancy: safety, patient tolerance and effect on obesity-related pregnancy outcomes. Obes Surg 2004; 14: 230-5. [CrossRef]
31. Shekelle PG, Newberry S, Maglione M, Li Z, Yermilov I, Hilton L, et al. Bariatric surgery in women of reproductive age: special concerns for pregnancy. Evid Rep Technol Assess (Full Rep) 2008; 169: 1-51.

32. Jefferys AE, Siassakos D, Draycott T, Akande VA, Fox R. Deflation of gastric band balloon in pregnancy for improving outcomes. Cochrane Database Syst Rev 2013; 4: 1-9. [CrossRef]

33. Woodard CB. Pregnancy following bariatric surgery. J Perinat Neonatal Nurs 2004; 18: 329-40. [CrossRef]

34. Sheiner E, Willis K, Yogev Y. Bariatric surgery: impact on pregnancy outcomes. Curr Diab Rep 2013; 13: 19-26. [CrossRef]

35. Hammoud A, Gibson M, Hunt SC, Adams TD, Carrell DT, Kolotkin RL, et al. Effect of Roux-en-Y gastric bypass surgery on the sex steroids and quality of life in obese men. J Clin Endocrinol Metab 2009; 94: 1329-32. [CrossRef]

36. di Frega AS, Dale B, Di Matteo L, Wilding M. Secondary male factor infertility after Roux-en-Y gastric bypass for morbid obesity: case report. Hum Reprod 2005; 20: 997-8. [CrossRef] 